$\begin{array}{lll}\text { Volume : } 1 & \text { No : } 2 \text { November } 2016 & \text { ISSN : } 2502-7069\end{array}$

\title{
PENGARUH KEPUASAN KERJA DAN KOMITMEN ORGANISASI TERHADAP KINERJA GURU SMK NEGERI DI KOTA MATARAM
}

Oleh :

\author{
Ramli Hidayat1, Nyoman Sridana2, Sudirman2 \\ Program Studi Magister Administrasi Pendidikan123 \\ Program Pascasarjana Universitas Mataram \\ dayatramly@gmail.com
}

\begin{abstract}
Abstrak : Penelitian ini bertujuan untuk: 1) mengetahui ada tidaknya pengaruh kepuasan kerja terhadap kinerja guru SMK Negeri di Kota Mataram, 2) mengetahui ada tidaknya pengaruh komitmen organisasi terhadap kinerja guru SMK Negeri di Kota Mataram, dan 3) mengetahui ada tidaknya pengaruh kepuasan kerja dan komitmen organisasi secara bersama-sama terhadap kinerja guru SMK Negeri di Kota Mataram. Penelitian ini menggunakan pendekatan penelitian kuantitatif, dimana peneliti menggambarkan fenomena yang diamati dengan lebih detail menggunakan data-data berupa data kuantitatif. Populasi penelitian ini adalah seluruh guru SMK Negeri di Kota Mataram yang berjumlah 416 guru. Sampel penelitian ini adalah sebagian dari jumlah guru SMK Negeri di Kota Mataram yang berjumlah 81 guru dengan menggunakan teknik proportionate random sampling. Hasil penelitian menunjukkan bahwa: 1) terdapat pengaruh kepuasan kerja terhadap kinerja guru SMK Negeri di Kota Mataram sebesar 33,7\% yang dibuktikan dengan nilai signifikansi $0,000<$ level of signifikan $(0,05) .2)$ terdapat pengaruh komitmen organisasi terhadap kinerja guru SMK Negeri di Kota Mataram sebesar 43,5 \% yang dibuktikan dengan nilai signifikansi $0,000<$ level of signifikan $(0,05)$. 3) terdapat pengaruh kepuasan kerja dan komitmen organisasi secara bersama-sama terhadap kinerja guru SMK Negeri di Kota Mataram sebesar 53,4 \% yang dibuktikan dengan nilai signifikansi $0,000<$ level of signifikan $(0,05)$.
\end{abstract}

Kata Kunci : Kepuasan Kerja, Komitmen Organisasi, Kinerja Guru

Abstract: This study aims to: 1) determine whether there is influence of job satisfaction on the performance of teachers at Vocational High School in Mataram, 2) determine whether there is influence of the organization's commitment to the performance of teachers at Vocational High School in Mataram, and 3) determine whether there is influence job satisfaction and commitment organizations together on teacher performance at Vocational High School in Mataram. This study uses a quantitative research approach, where researchers describe the phenomenon hat observed in more detail using the data in the form of quantitative data. The study population was 
all teachers at Vocational High School in Mataram which amounted to 416 teachers. Samples were mostly of teachers at Vocational High School in Mataram numbering 81 teachers using proportionate random sampling technique. The results showed that: 1) there is the influence of job satisfaction on the performance of teachers at Vocational High School in Mataram at $33.7 \%$ as evidenced by the significant value of $0.000<$ level of significance (0.05). 2) there is influence of the organization's commitment to the performance of teachers at Vocational High School in Mataram 43.5\% as evidenced by the significant value of $0.000<$ level of significance (0.05). 3) there is influence job satisfaction and organizational commitment together on teacher performance at Vocational High School in Mataram 53.4\% as evidenced by the significant value of $0.000<$ level of significance (0.05).

\section{Key Word: $\quad$ Job Satisfaction, Organization Commitment, Teacher Performance}

\section{PENDAHULUAN}

Pendidikan adalah faktor utama dalam menentukan kualitas kehidupan bangsa. Peran pendidikan sangat penting untuk menciptakan kehidupan yang cerdas, damai, terbuka, dan demokratis. Dengan pendidikan akan menghasilkan sumber daya manusia yang handal. Fenomena yang dimaksud tentu menjadi tanggung jawab banyak pihak terutama dunia pendidikan dimana ujung tombaknya adalah guru. Kondisi sekarang ini belum menunjukkan hasil yang maksimal, sehingga masih diperlukan berbagai upaya dan strategi yang tepat, guna meningkatkan kinerja guru, dengan harapan terjadi peningkatan kualitas pengajaran dan pembelajaran di sekolah. Undang-Undang Nomor 14 Tahun 2005 tentang Guru dan Dosen menyatakan bahwa guru adalah pendidik profesional dengan tugas utama mendidik, mengajar, membimbing, mengarahkan, melatih, menilai dan mengevaluasi peserta didik pada pendidikan anak usia dini jalur prndidikan formal, pendidikan dasar dan pendidikan menengah. Guru profesional harus memiliki kualifikasi akademik minimum sarjana (S1) atau diploma empat (D-IV), mengetahui kompetensi (pedagogik, profesional, sosial dan kepribadian), memiliki sertifikat pendidik, sehat jasmani dan rohani, sesuai tujuan pendidikan nasional.

Tujuan Pendidikan Nasional dalam Sisdiknas dapat tercapai jika ada peran yang dominan dari guru yang profesional. Tenaga pendidik yang profesional dapat terwujud apabila dalam melaksanakan tugasnya telah memiliki kompetensi yang ingin dicapai. Upaya pemerintah dalam mencetak guru yang profesional telah dilaksanakan dengan uji kompetensi guru, diharapkan dengan uji kompetensi dapat mengetahui guru yang berkualitas sehinggan nantinya akan berdampak pada pengajaran dan pendidikan yang berkualitas.

Kinerja berarti sesuatu yang dicapai, kemampuan kerja, atau prestasi yang diperlihatkan (Depdikbud, 1999: 503). Maier (dalam As'ad, 1991: 47) kinerja diartikan sebagai kesuksesan seseorang dalam melaksanakan suatu pekerjaan. Lawer and Poter menegaskan kinerja yaitu "succesfull role achievement" yang diperoleh dari perbuatan-perbuatannya. Dari beberapa pengertian di atas, kinerja dapat diartikan sebagai suatu hasil yang dicapai seseorang menurut ukuran yang berlaku untuk pekerjaan yang bersangkutan.

Upaya peningkatan mutu guru sebagai 
tenaga profesional, dipandang perlu untuk dilakukan pembinaan pengembangan profesi dan karier guru. Disusul dengan terbitnya Peraturan Pemerintah No 14 Tahun 2005 tentang Standar Nasional Pendidikan, dan Peraturan Menteri Pendidikan Nasional Republik Indonesia, Nomor 16 Tahun 2007 tentang Standar Kualifikasi Akademik dan Kompetensi Guru.

Dengan merujuk pada pengertian tentang kinerja di atas, maka jika seseorang itu adalah guru, dapat dikatakan bahwa kinerja guru adalah proses kerja dan keberhasilan kerja guru dalam melaksanakan tugas dan kewajibannya sesuai dengan tujuan, visi, dan misi sekolah tempatnya bertugas, tentunya dengan senantiasa merujuk pada aturan-aturan di sekolah yang ditetapkan oleh atasannya.

Gambaran umum tentang kinerja guru yang ideal disampaikan oleh Siswanto (2003) menyatakan, terdapat beberapa unsur yang perlu mendapat perhatian dalam pengukuran kinerja guru, yaitu: (1) Kesetiaan, (2) prestasi kerja, dan (3) tanggung Jawab, (4) ketaatan, (5) kejujuran, (6) kerja Sama, (7) prakarsa, dan (8) kepemimpinan. Pandangan yang hampir sama tentang kinerja guru disampaikan oleh Saerozi (dalam Bahri, 2005: 2), menyebutkan beberapa faktor yang dapat mempengaruhi kinerja guru dalam melaksanakan tugasnya, yaitu: (a) kepemimpinan kepala sekolah, (b) fasilitas kerja, (c) harapan-harapan, dan (d) kepercayaan personalia sekolah.

Saat ini, kenyataan yang terjadi di lapangan bahwa kinerja guru masih dikatakan belum maksimal, termasuk guru-guru SMK Negeri yang ada di Kota Mataram. Hal ini dapat dibuktikan dari hasil Uji Kompetensi Guru yang menunjukkan bahwa hanya $10 \%$ guru di NTB yang mendapat skor di atas 5,5 (Sudirman, 2015:1). Artinya, dengan kompetensi yang redah tersebut menunjukkan kinerja guru di NTB masih rendah karena kompetensi guru berpengaruh fositif terhadap kinerja guru. Hasil penelitian Yuliandi (2014:114) bahwa kompetensi guru berpengaruh positif terhadap kinerja guru.

Rendahnya kinerja guru seperti yang disebutkan di atas tentu menjadi perhatian kita bersama agar sedapat mungkin kinerja guru tersebut dapat ditingkatkan. Salah satu faktor yang dapat meningkatkan kinerja guru adalah kepuasan kerja guru. Hal ini sesuai dengan hasil penelitian yang dilakukan oleh Werang (2014) bahwa kepuasan kerja guru berpengaruh secara positif dan signifikan terhadap kinerja guru.

Falah (2003), menyatakan bahwa kepuasan dalam menjalankan tugas merupakan hal yang penting bagi kinerja atau produktivitas seseorang. Suatu gejala yang dapat merusak kondisi organisasi sekolah adalah rendahnya kepuasan guru dimana timbul gejala seperti: kemangkiran, malas bekerja, banyaknya keluhan guru, rendahnya prestasi kerja, rendahhnya kualitas pengajaran, indisipliner guru. Kepuasan kerja adalah suatu perasaan positif tentang pekerjaan seseorang yang merupakan hasil dari sebuah evaluasi karakteristiknya Robbins dan Judge (2008:107). Menurut Luthans (2006:243), terdapat lima dimensi kepuasan kerja, yaitu: pembayaran, pekerjaan itu sendiri, kesempatan promosi, supervisor, dan rekan kerja.

Hughes et al. (2012:337), menyatakan bahwa kepuasan kerja berhubungan dengan sikap seseorang mengenai kerja, dan ada beberapa alasan yang membuat kepuasan kerja merupakan konsep yang penting bagi pemimpin. Penelitian menunjukkan pekerja yang puas lebih cenderung bertahan bekerja untuk organisasi. Pekerja yang puas juga 
cenderung terlibat dalam perilaku organisasi yang melampaui deskripsi tugas dan peran mereka, serta membantu mengurangi beban kerja dan tingkat stres anggota lain dalam organisasi. Pekerja yang tidak puas cenderung bersikap menentang dalam hubungannya dengan kepemimpinan dan terlibat dalam berbagai perilaku yang kontraproduktif. Ketidakpuasan juga alasan utama seseorang meninggalkan organisasi.

$$
\text { Castillo dan Cano }
$$

mengemukakan beberapa faktor yang menyebabkan kepuasan dan ketidakpuasan kerja, yaitu: (1) Pengakuan (recognition), Tindakan berupa pujian ataupun sikap menyalahkan yang disampaikan oleh atasan, rekan sejawat, manajemen, klien, dan atau masyarakat umum. (2) Pencapaian (achievement), Segala upaya yang dilakukan untuk meraih keberhasilan termasuk mengambil sikap atas kegagalan yang terjadi.

(3) Kesempatan berkembang (possibility of growth), Adanya kesempatan untuk berkembang yang tercermin dari perubahan status. (4) Kemajuan (advancement), Perubahan nyata yang terjadi pada status pekerjaan. (5) Gaji (salary), Konsekuensi dari kompensasi yang memainkan peran utama. (6) Hubungan antar pribadi (interpersonal relations), Hubungan yang terjalin antara atasan, bawahan, dan rekan sejawat. (7) Pengawasan (supervision), Kemampuan pengawas dalam mendelegasikan tanggung jawab dan membimbing bawahan. (8) Tanggung jawab (responsibility), Kepuasan yang timbul berasal dari adanya kendali dan tanggung jawab yang diberikan dalam suatu pekerjaan. (9) Administrasi dan kebijakan (policy and administration), Tindakan dimana beberapa aspek atau secara keseluruhan berdampak pada kepuasan kerja. (10) Kondisi kerja (working condition), Berhubungan dengan kondisi kerja secara fisik seperti fasilitas kerja dan kualitas pekerjaan.

Selain kepuasan kerja, faktor yang mempengaruhi kinerja guru adalah komitmen organisasi. Menurut Durkin dan Bennet (1999) Komitmen organisasional didefinisikan sebagai perasaan yang kuat dan erat dari seseorang terhadap tujuan dan nilai suatu organisasi dalam hubungannya dengan peran mereka terhadap upaya pencapaian tujuan dan nilai-nilai tersebut. Luthans (2006:249) menyatakan bahwa komitmen organisasional merupakan sikap yang menunjukkan loyalitas karyawan dan merupakan proses berkelanjutan bagaimana seorang anggota organisasi mengekspresikan perhatian mereka kepada kesuksesan dan kebaikan organisasinya. Lebih lanjut sikap loyalitas ini diindikasikan dengan tiga hal, yaitu: (1) keinginan kuat seseorang untuk tetap menjadi anggota organisasinya; (2) kemauan untuk mengerahkan usahanya untuk organisasinya; (3) keyakinan dan penerimaan yang kuat terhadap nilai-nilai dan tujuan organisasi. Komitmen organisasional akan membuat pekerja memberikan yang terbaik kepada organisasi tempat dia bekerja. Pekerja dengan komitmen yang tinggi akan lebih berorientasi pada kerja. Pekerja yang memiliki komitmen organisasional tinggi akan cenderung senang membantu dan dapat bekerjasama.

Komitmen organisasional dipengaruhi oleh kepuasan kerja. Aydogdu dan Asikgil (2011) meneliti hubungan antara kedua variabel ini dan menemukan bahwa kepuasan kerja memiliki hubungan yang signifikan dan positif terhadap tiga dimensi komitmen organisasional, yaitu komitmen afektif, komitmen berkelanjutan, dan komitmen normatif. Hubungan positif moderat signifikan 
juga ditemukan antara aspek kepuasan kerja, faktor demografi, dan komitmen organisasional pada penelitian yang dilakukan oleh Azeem (2010). Penelitian yang dilakukan oleh Karim dan Rehman (2012) menunjukkan bahwa kepuasan kerja dan keadilan organisasi secara signifikan mempengaruhi komitmen organisasional.

Komitmen organisasional dapat digunakan untuk memprediksi aktivitas profesional dan perilaku kerja karena komitmen organisasional mencerminkan sikap positif individu pada organisasi. Sikap ini memotivasi seseorang untuk berperilaku positif, untuk menjadi disiplin dalam bekerja, untuk mematuhi aturan dan kebijakan organisasi, untuk menjaga hubungan baik dengan rekan kerja, dan meningkatkan tingkat pencapaian seseorang. Dengan cara ini, pengetahuan dan pemahaman tentang komitmen organisasi dapat digunakan sebagai dasar untuk memprediksi perilaku kerja individu (Sahertian dan Soetjipto, 2011).

Berdasarkan pemaparan di atas, kaitan komitmen organasi dengan komitmen guru di sekolah tidak jauh berbeda. Dalam bekerja guru harus memiliki rasa tanggung jawab dan dedikasi yang tinggi terhadap pekerjaan itu sendiri maupun terhadap lingkungan pekerjaannya. Guru akan bekerja dengan penuh rasa tanggung jawab dan dedikasi yang tinggi jika memiliki komitmen organisasi. Schatz (1995:135) mengatakan bahwa komitmen merupakan hal yang paling mendasar bagi setiap orang dalam menggeluti profesinya. Keberhasilan seseorang dalam suatu tugas yang diberikan kepadanya ditentukan oleh bagaimana komitmen mereka pada tugas dan tingkat pendidikan atau pengetahuannya. Tanpa adanya suatu komitmen, tugas-tugas yang diberikan kepadanya sukar untuk dilaksanakan dengan baik.

Senada dengan hal ini, Nawawi (1993:47) mengatakan bahwa komitmen guru selain tumbuh dari dalam diri masing-masing, juga dipengaruhi oleh kepala sekolah sebagai pimpinan. Unsur lain yang dapat meningkatkan komitmen pada organisasi tempat bekerja ditentukan oleh tingkat upah, kondisi dan budaya tempat bekerja, berbagai macam tunjangan kesejahteraan, jaminan kerja yang baik. Selain itu pujian, penghargaan, ucapan terima kasih dari pimpinan dan rekan sejawat sangat berpengaruh terhadap peningkatan komitmen seseorang. Komitmen guru merupakan hal yang amat penting dalam upaya meningkatkan kinerja sekolah, baik secara personal maupun organisasional. Dengan komitmen yang tinggi akan mendorong rasa percaya diri dan semangat kerja bagi guru. Komitmen akan memperlancar pergerakan sekolah mencapai goal setting perubahan, ini ditandai dengan terciptanya peningkatan, baik bersifat fisik maupun psikologis, sehingga segala sesuatunya menjadi menyenangkan bagi seluruh warga sekolah.

\section{METODE PENELITIAN}

Penelitian ini dilaksanakan di Sekolah Menengah Kejuruan Negeri di Kota Mataram terhitung mulai bulan Februari sampai dengan bulan Juli 2016. Populasi dalam penelitian ini adalah seluruh Guru Tetap (GT) yang tersebar pada 9 SMK Negeri di Kota Mataram sejumlah 416 orang. Penentuan jumlah sampel menggunakan persamaan menurut pandangan dari Al-Rasyid (Riduwan, 2014) seperti berikut:

$$
n o=\left(\frac{z \alpha}{2 \cdot B E}\right)^{2}
$$


Keterangan:

$\alpha \quad$ : Taraf kesalahan yang besarnya ditetapkan sebesar 0,05

$\mathrm{N} \quad$ : Populasi sampel

BE : Bound of Error diambil 10\%

$\mathrm{Z} \alpha \quad$ : Nilai dalam tabel $\mathrm{Z}=1,99$

no $=(\mathrm{z} \alpha /(2 \cdot \mathrm{BE})) 2=(1,99 /(2 .(0,10))) 2$

no $=(9,95) 2=99,0025$;

no $=0,05 \mathrm{~N}=0,05 \times 416=20,8$

Karena no $>0,05 \mathrm{~N}$ atau 99,0025 $>20,8$, maka besarnya sampel dapat dihitung denga rumus:

$$
n=\frac{n o}{1+\frac{n o-1}{N}}=\frac{99,0025}{1+\frac{99,025-1}{416}}=\frac{99,0025}{1,235}=
$$

$80,12 \approx 80$ orang guru.

Jumlah sampel penelitian sebanyak 80 orang yang diambil menggunakan teknik proportionate random sampling.

Instrumen penelitian yang dipakai sebagai alat ukur variabel penelitian adalah angket model skala Likert dengan 4 (empat) pilihan jawaban. Sugiyono (2009) mengatakan bahwa skala tersebut dapat digunakan untuk mengukur sikap, pendapat dan persepsi seseorang atau sekelompok orang tentang fenomena tertentu. Pemilihan instrumen kuesioner (angket) model skala
Likert berdasarkan pada pertimbangan bahwa dengan instrumen ini jawaban responden dapat diperoleh secara memadai dan memudahkan dalam pengolahan/ mendeskripsikan hasilnya serta sesuai dengan tujuan yang hendak dicapai dalam penelitian ini.

Teknik analisis data yang dipergunakan dalam penelitian ini adalah analisis regresi, baik regresi sederhana maupun regresi ganda. Sebelum analisis data dilaksanakan, terlebih dahulu dilakukan deskripsi data penelitian yang terdiri dari 2 (dua) variabel bebas dan 1 (satu) variabel terikat dalam bentuk tabel data, distribusi frekuensi, dan histogram. Langkah berikutnya adalah melaksanakan uji persyaratan analisis data yang meliputi uji normalitas, homogenitas data, multikolinieritas, dan autokorelasi.

\section{HASIL DAN PEMBAHASAN}

Data-data yang dikumpulkan dalam penelitian ini bertujuan untuk mendapatkan gambaran tentang komitmen organisasi dan kepuasan kerja terhadap kinerja guru SMK Negeri di Kota Mataram. Deskripsi data tentang kepuasan kerja, komitmen organisasi dan kinerja guru dapat ditunjukkan seperti Gambar 1 berikut ini:

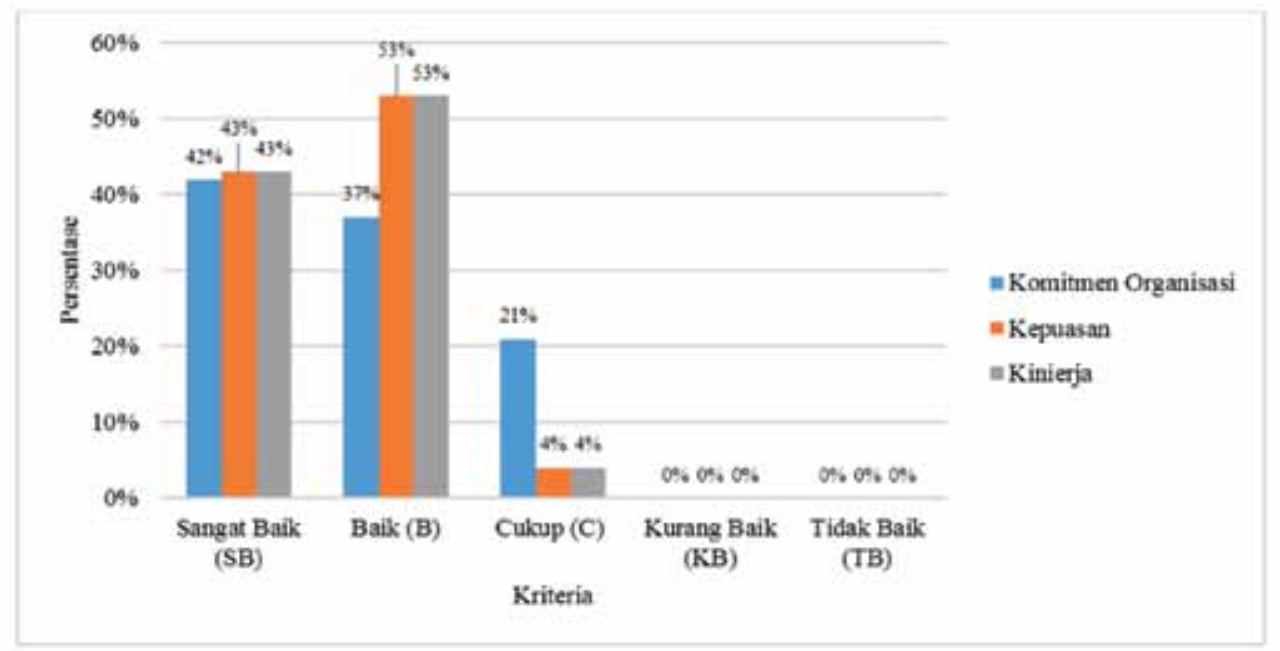

Gambar 1. Grafik Deskripsi Data Hasil Penelitian 
Terlihat pada Grafik 1 di atas, menurut responden sebanyak $43 \%$ kepuasan kerja guru SMK Negeri di Kota Mataram dalam kategori sangat baik, 53\% dalam kategori baik, dan 4\% dalam kategori cukup. Menurut responden sebanyak 42\% komitmen organisasi guru SMK Negeri di Kota Mataram dalam kategori sangat baik, 37\% dalam kategori baik, dan 21\% dalam kategori cukup. Menurut responden sebanyak 43\% kinerja guru SMK Negeri di Kota Mataram dalam kategori sangat baik, $53 \%$ dalam kategori baik, dan $4 \%$ dalam kategori cukup.

Sebelum analisis data, terlebih dahulu dilakukan uji normalitas, homogenitas, multikolinieritas, dan autokorelasi. Dari hasil uji yang dilakukan menunjukkan bahwa semua data telah memenuhi syarat untuk dilakukan uji hipotesis dengan menggunakan uji statistik. Adapun hasil uji statistik untuk melihat pengaruh variabel bebas terhadap bariabel terikat yang dapat dirangkum dalam Tabel 1 berikut:

Tabel 1. Hasil Uji Regresi Sederhana

\begin{tabular}{llccc}
\hline No & \multicolumn{1}{c}{$\begin{array}{c}\text { Pengaruh Variabel Bebas terhadap } \\
\text { Variabel terikat }\end{array}$} & Signifikan & $\begin{array}{c}\text { Persen- } \\
\text { tase }\end{array}$ & Keterangan \\
\hline 1 & $\begin{array}{l}\text { Pengaruh kepuasan kerja guru terhadap } \\
\text { kinerja guru SMK Negeri di Kota Mataram }\end{array}$ & 0.000 & $33,7 \%$ & Signifikan \\
\hline 2 & $\begin{array}{l}\text { Pengaruh komitmen organisasi terhadap } \\
\text { kinerja guru SMK Negeri di Kota Mataram }\end{array}$ & 0.000 & $43,5 \%$ & Signifikan \\
\hline 3 & $\begin{array}{l}\text { Pengaruh kepuasan kerja guru dan } \\
\text { komitmen organisasi secara bersama-sama } \\
\text { terhadap kinerja guru SMK Negeri di Kota } \\
\text { Mataram }\end{array}$ & & $53,4 \%$ & Signifikan \\
& & & \\
\hline
\end{tabular}

Berdasarkan Tabel 1 di atas sehingga H0 di tolak. Besarnya koefisien menunjukkan bahwa variabel bebas baik regresi untuk variabel penelitian diperoleh secara parsial maupun secara bersama berdasarkan Tabel 2 sebagai berikut: memiliki pengaruh terhadap variabel terikat

\begin{tabular}{|c|c|c|c|c|c|c|c|c|}
\hline \multirow{2}{*}{\multicolumn{2}{|c|}{ Model }} & \multicolumn{2}{|c|}{$\begin{array}{l}\text { Unstandardized } \\
\text { Coefficients }\end{array}$} & \multirow{2}{*}{$\begin{array}{c}\text { Standardized } \\
\text { Coefficients } \\
\text { Beta } \\
\end{array}$} & \multirow[b]{2}{*}{$\mathrm{t}$} & \multirow[b]{2}{*}{ Sig. } & \multicolumn{2}{|c|}{$\begin{array}{l}\text { Collinearity } \\
\text { Statistics }\end{array}$} \\
\hline & & B & Std. Error & & & & Tolerance & VIF \\
\hline \multirow[t]{2}{*}{1} & (Constant) & 41.633 & 6.944 & & 5.996 & .000 & & \\
\hline & Kepuasan & .547 & .086 & .581 & 6.338 & .000 & 1.000 & 1.000 \\
\hline \multirow[t]{2}{*}{2} & (Constant) & 42.254 & 5.578 & & 7.575 & .000 & & \\
\hline & Komitmen & .546 & .070 & .659 & 7.795 & .000 & 1.000 & 1.000 \\
\hline
\end{tabular}

Berdasarkan Tabel 2 di atas, koefisien regresi pengaruh kepuasan kerja guru sebesar 0,547, dan konstantanya sebesar 41,633, sehingga persamaan regresi sederhana pengaruh kepuasan kerja terhadap kinerja guru adalah $\bar{Y}=41,633+0,547 X 2$. Hal ini berarti perubahan satu unit persepsi pada peubah kepuasan kerja (X2) akan diikuti oleh perubahan kinerja guru (Y) sebesar 0,547 unit pada arah yang sama $(41,633)$. Koefisien regresi komitmen organisasi sebesar 0,546, dan konstantanya sebesar 42,254, sehingga persamaan regresi sederhana pengaruh komitmen organisasi terhadap kinerja guru 
adalah $\bar{Y}=42,254+0,546 X 1$. Hal ini berarti perubahan satu unit persepsi pada peubah komitmen organisasi (X1) akan diikuti oleh perubahan kinerja guru (Y) sebesar 0,546 unit pada arah yang sama $(42,254)$.

Berdasarkan hasil pengujian hipotesis menunjukkan bahwa semua hipotesis statistik (H0) dalam penelitian ini dapat ditolak pada taraf signifikansi 0,05, dengan demikian antara variabel bebas yang diteliti terdapat pengaruh terhadap variabel terikat, yaitu: (1) antara komitmen organisasi terhadap kinerja guru SMK Negeri di Kota Mataram, (2) antara kepuasan kerja terhadap kinerja guru SMK Negeri di Kota Mataram, dan (3) antara komitmen organisasi dan kepuasan kerja secara bersama-sama terhadap kinerja guru SMK Negeri di Kota Mataram.

Kepuasan kerja yang ditunjukkan di lingkungan SMK Negeri di Kota Mataram tergolong baik. Data yang diperoleh menunjukkan bahwa sebanyak 43\% guru memandang bahwa kepuasan kerja di sekolahnya sangat baik. Kepuasan kerja guru SMK Negeri di Kota Mataram tergolong baik karena salah satu penyebabnya adalah kepedulian seorang pemimpin terhadap permasalahan yang dihadapi bawahannya. Guru merasa puas karena mendapatkan perhatian dariatasannnya. Hal ini sesuaidengan jawaban responden tentang kesejahteraan guru menunjukkan persentase yang sangat baik. Selain itu, berdasarkan hasil analisis data, terdapat 53\% guru yang menyatakan bahwa kepuasan kerja di sekolahnya dalam kategori baik, dan 4\% guru menyatakan bahwa kepuasan kerja dalam kategori cukup. Castillo dan Cano (2004) mengemukakan beberapa faktor yang menyebabkan kepuasan dan ketidakpuasan kerja, yaitu: (1) Pengakuan (recognition), Tindakan berupa pujian ataupun sikap menyalahkan yang disampaikan oleh atasan, rekan sejawat, manajemen, klien, dan atau masyarakat umum. (2) Pencapaian (achievement), Segala upaya yang dilakukan untuk meraih keberhasilan termasuk mengambil sikap atas kegagalan yang terjadi. (3) Kesempatan berkembang (possibility of growth), Adanya kesempatan untuk berkembang yang tercermin dari perubahan status. (4) Kemajuan (advancement), Perubahan nyata yang terjadi pada status pekerjaan. (5) Gaji (salary), Konsekuensi dari kompensasi yang memainkan peran utama. (6) Hubungan antar pribadi (interpersonal relations), Hubungan yang terjalin antara atasan, bawahan, dan rekan sejawat. (7) Pengawasan (supervision), Kemampuan pengawas dalam mendelegasikan tanggung jawab dan membimbing bawahan. (8) Tanggung jawab (responsibility), Kepuasan yang timbul berasal dari adanya kendali dan tanggung jawab yang diberikan dalam suatu pekerjaan. (9) Administrasi dan kebijakan (policy and administration), Tindakan dimana beberapa aspek atau secara keseluruhan berdampak pada kepuasan kerja. (10) Kondisi kerja (working condition), Berhubungan dengan kondisi kerja secara fisik seperti fasilitas kerja dan kualitas pekerjaan.

Komitmen organisasi merupakan aplikasi sejauh mana seseorang memihak terhadap sebuah organisasi dan tujuantujuannya serta keinginannya untuk mempertahankan keanggotaannya dalam sebuah organisasi. Jika orang tersebut adalah guru, maka komitmen guru adalah suatu keterikatan diri terhadap tugas dan kewajiban sebagai guru yang dapat melahirkan tanggung jawab dan sikap responsif dan inovatif terhadap perkembangan ilmu pengetahuan dan teknologi. 
Berdasarkan hasil analisis data menunjukkan bahwa komitmen organisasi menurut persepsi guru SMK Negeri di Kota Mataram tergolong baik, namun masih ada yang tergolong cukup. Berdasarkan data sebanyak $42 \%$ komitmen organisasi menurut pandangan guru tergolong sangat baik, sebanyak 37\% tergolong baik, dan sebanyak $21 \%$ tergolong cukup.

Persepsi guru tentang komitmen organisasi seperti hasil tersebut menunjukkan bahwa, masih ada guru yang memiliki komitmen yang belum maksimal. Hal ini terjadi karena guru belum memiliki kesadaran dalam membimbing siswa di luar jam sekolah. Guru hanya melakukan tugasnya dalam membimbing ketika tatap muka di dalam kelas. Pernytaan tersebut didasari atas jawaban responden terhadap instrumen komitmen No. 17 yang berbunyi "sebagai guru saya melakukan pembimbingan siswa pada jam di luar jam sekolah untuk meningkatkan pengetahuan". Jawaban responden terhadap pernyataan tersebut adalah $37 \%$ responden menyatakan bahwa guru jarang melakukan hal tersebut.

Komitmen organisai guru adalah suatu keterikatan diri terhadap tugas dan kewajiban sebagai guru yang dapat melahirkan tanggung jawab dan sikap responsif dan inovatif terhadap perkembangan ilmu pengetahuan dan teknologi.

Berbicara tentang kinerja guru, maka kinerja guru merupakan proses kerja dan keberhasilan kerja guru dalam melaksanakan tugas dan kewajibannya sesuai dengan tujuan, visi, dan misi sekolah tempatnya bertugas, tentunya dengan senantiasa merujuk pada aturan-aturan di sekolah yang ditetapkan oleh atasannya. Berdasarkan hasil analisis data, kinerja guru SMP Negeri di Kota Mataram terdapat $43 \%$ tergolong dalam kategori baik,
$53 \%$ kinerja guru tergolong dalam kategori sedang (kurang baik), dan 4\% kinerja guru tergolong masih rendah. Hal ini menunjukkan bahwa, kinerja guru perlu untuk ditingkatkan. Gambaran umum tentang kinerja guru yang ideal disampaikan oleh Siswanto (2003) menyatakan, terdapat beberapa unsur yang perlu mendapat perhatian dalam pengukuran kinerja guru, yaitu: (1) Kesetiaan, (2) prestasi kerja, dan (3) tanggung Jawab, (4) ketaatan, (5) kejujuran, (6) kerja Sama, (7) prakarsa, dan (8) kepemimpinan. Rendahnya kinerja guru seperti hasil analisis di atas disebabkan karena beberapa unsur menurut Siswanto tersebut belum dilaksanakan sepenuhnya.

Berdasarkan hasil analisis data bahwa hipotesis pertama yang menyatakan terdapat pengaruh kepuasan kerja terhadap kinerja guru SMK Negeri di Kota Mataram diterima. Pengaruh kepuasan kerja terhadap kinerja guru SMK Negeri di Kota Mataram sebesar $33,7 \%$. Hal ini sesuai dengan hasil penelitian yang dilakukan oleh Hutabarat (2015) bahwa terdapat pengaruh kepuasan kerja terhadap kinerja. Hasil penelitian tersebut menunjukkan bahwa semakin tinggi tingkat kepuasan kerja guru akan diikuti oleh semakin meningkatnya kinerja guru SMK Negeri di Kota Mataram.

Beberapa pendapat sebelumnya juga memberikan pengertian mengenai pengaruh kepuasan kerja terhadap kinerja karyawan seperti yang disampaikan oleh Kreitner dan Kinicki (2001) berpendapat bahwa ketidakpuasan kerja memiliki suatu pengaruh tidak langsung pada kesalahan kerja karyawan secara nyata yang nantinya akan berpengaruh secara langsung pada pembentukan kinerja. Robbins (2001) juga berpendapat faktor-faktor yang dapat digunakan untuk meningkatkan kinerja pegawai, diantaranya motivasi dan kepuasan kerja. 
Berdasarkan hasil analisis bahwa hipotesis kedua yang menyatakan bahwa terdapat pengaruh komitmen organisasi terhadap kinerja guru SMK Negeri di Kota Mataram diterima. Besarnya pengaruh komitmen organisasi terhadap kinerja guru sebesar 43,5\%.Artinya bahwa, semakin baik komitmen organisasi di sekolah akan diikuti dengan meningkatnya kinerja guru SMK Negeri di Kota Mataram. Hasil penelitian ini sejalan dengan hasil penelittian yang dilakukan oleh Khan et al (2010) bahwa komitmen organisasi berpengaruh terhadap kinerja karyawan.

Pengaruh komitmen organisasi terhadap kinerja karyawan juga dijelaskan oleh beberapa pendapat diantarnya adalah Boulian dan Mowday (1974) dalam Tobing (2009) telah menyatakan bahwa refleksi kekuatan keterlibatan dan kesetiaan karyawan terhadap organisasi, jika komitmen karyawan terhadap organisasinya tinggi maka akan berpengaruh terhadap kinerja, sedangkan kalau komitmen karyawan ini rendah maka pengaruh terhadap kinerja juga rendah bahkan dapat mengakibatkan munculnya keinginan untuk keluar bekerja atau pindah kerja. Wagner (dalam Karsono, 2008) berpendapat bahwa salah satu faktor yang mempengaruhi kinerja adalah tingkat dimana seseorang merasa komit dengan suatu tujuan. Tujuan khusus dan menyulitkan akan berperan atas peningkatan kinerja hanya ketika ada komitmen pada tujuan yang tinggi.

Berdaarkan hasil analisis, hipotesis ketiga yang menyatakan terdapat pengaruk kepuasan kerja dan komitmen organisasi secara bersama-sama terhadap kinerja guru SMK Negeri di Kota Mataram diterima. Besaran pengaruhnya kepuasan kerja dan kinerja guru secara bersama-sama terhadap kinerja guru sebesar 53,4\%. Artinya bahwa, semakin baik kepuasan kerja yang diikuti dengan peningkatan komitmen organisasi akan diikuti dengan meningkatnya kinerja guru SMK Negeri di Kota Mataram.

Panggabean (2004) keberhasilan dan kinerja seseorang dalam suatu bidang pekerjaan banyak ditentukan oleh tingkat kompetensi, profesionalisme juga komitmen terhadap bidang yang ditekuninya. Suatu komitmen organisasional menunjukkan suatu daya dari sesorang dalam mengidentifikasikan keterlibatan dalam suatu organisasi. Oleh karena itu komitmen organisasional akan menimbulkan rasa ikut memiliki (sense of belonging) bagi pekerja terhadap organisasi. Disamping komitmen organisasi, adanya orientasi professional yang mendasari komitmen profesional nampaknya juga akan berpengaruh terhadap kepuasan kerja yang berarti bahwa karyawan hanya akan memiliki komitmen terhadap organisasi jika mereka merasa telah puas terhadap gaji, promosi, pimpinan, rekan kerja dan kondisi kerjanya. Sehingga dapat dikatakan komitmen organisasi adalah perpaduan antara sikap dan prilaku. Komitmen organisasi menyangkut tiga sikap yaitu mengidentifikasi dengan tujuan organisasi, keterlibatan dengan tugas organisasi dan kesetiaan pada organisasi.

Guru SMK Negeri di Kota Mataram sepertinya tidak pernah puas dengan apa yang didapat, seperti gaji yang tinggi dan sebagainya. Karena itu salah satu tugas kepala sekolah adalah harus dapat menyesuaikan antara keinginan para guru dengan tujuan dari sekolah. Walaupun kepuasan kerja pada dasarnya merupakan suatu cara pandang seseorang baik yang bersifat positif maupun bersifat negatif tentang pekerjaannya. Siagian, (2003: 295) menjelaskan walaupun kepuasan kerja pada dasarnya merupakan suatu cara 
pandang seseorang baik yang bersifat positif naupun bersifat negatif tentang pekerjaanya.

Guru yang merasa puas akan pekerjaan yang dilakukan di sekolah baik diliat dari kepuasan akan gaji yang diterima, dan terbukanya promosi peluang guru untuk promosi dalam mengembangkan karir serta adanya hubungan baik yang terjalin sesama guru dan juga memiliki komitmen yang tinggi terhadap organisasi yang dilihat dari kemauan untuk mematuhi peraturan dan loyal terhadap perusahaan akan menghasilkan kinerja yang baik bagi sekolah.

Uraian prmbahasan di atas menunjukkan bahwa kinerja guru memang harus ditingkatkan untuk dapat mencapai tujuan pendidikan yang telah ditentukan. Guru memiliki peranan pnting dalam meningkatkan pendidikan, untuk itu kinerja guru perlu ditingkatkan. Dalam meningkatkan kinerja guru, faktor penting yang harus diperhatikan adalah kepuasan kerja guru itu ssendiri dan bagaimana komitmennya dalam bekerja, untuk itu, peningkatan kepuasan kerja dan komitmen organisasi harus dilakukan agar kinerja guru juga dapat meningkat dengan baik.

\section{KESIMPULAN}

Berdasarkan hasil yang diperoleh dalam penelitian ini maka dapat ditarik kesimpulan sebagai berikut:

Terdapat pengaruh kepuasan kerja terhadap kinerja guru SMK Negeri di Kota Mataram sebesar 33,7\%. Hal ini menunjukkan bahwa semakin baik kepuasan kerja akan diikuti oleh peningkatan kinerja guru SMK Negeri di Kota Mataram.

Terdapat pengaruh komitmen organisasi terhadap kinerja guru SMK Negeri di Kota Mataram sebesar 43,5\%. Hal ini menunjukkan bahwa semakin baik komitmen organisasi akan diikuti oleh peningkatan kinerja guru SMK Negeri di Kota Mataram.

Terdapat pengaruh kepuasan kerja dan komitmen organisasi secara bersama-sama terhadap kinerja guru SMK Negeri di Kota Mataram sebesar 53,4\%. Hal ini menunjukkan bahwa semakin baik kepuasan kerja yang diikuti oleh peningkatan komitmen organisasi akan diikuti oleh peningkatan kinerja guru SMK Negeri di Kota Mataram.

\section{DAFTAR PUSTAKA}

As'ad, Moh.

1991. Psikologi Industri. Yogyakarta: Liberty

Aydogdu, S., and Asikgil, B.

2011. An Empirical Study of the Relationship Among Job Satisfaction, Organizational Commitment and Turnover Intention, International Review of Management and Marketing, Vol 1, No 3, pp.43-53.

Azeem, S.M.

2010. Job Satisfaction and Organizational Commitment among Employees in the Sultanate of Oman, Journal of Psychology, Vol 1, pp. 295- 299.

Bahri, Saiful.

2010. Peranan Kepemimpinan Kepala

Sekolah dan Iklim Sekolah Terhadap Kinerja Guru. Visipena. 1, (2).

Castillo, J.X., and Cano, J.

2004. Factors Explaining Job Satisfaction Among Faculty, Journal of Agricultural Education, Vol 45, No 3, pp. 65-74.

Durkin, M., and Bennet, $\mathrm{H}$.

1999. Employee commitment in retail banking: identifying and exploring hidden dangers, The International Journal of Bank Marketing, Vol17, No 3, pp. 124-137. 
Falah, Y.

2003. Studi Korelasi Antara Iklim Organisasi dan Motivasi Berprestasi Dengan Kepuasan Kerja Guru SMKN di Samarinda. [Online]. http://www. guruvalah.20m.com/iklim_motiv_ kinerja2b.pdf. (02Juli 2009)

Hughes, R.L., Ginnett, R.C., and Curphy, G.J. 2012. Leadership: Memperkaya Pelajaran dari Pengalaman, Edisi Ketujuh, Jakarta: Salemba Humanika.

Hutabarat, Wesly.

2015. The Impact of Organizational Culture, Organizational Structure, and Job-Satisfaction on High School Teachers' Job-Performance. Cakrawala Pendidikan. XXXIV (3).

Karim, F., and Rehman, O.

2012. Impact of Job Satisfaction, Perceived Organizational Justice and Employee Empowerment on Organizational Commitment in SemiGovernment Organizations of Pakistan. Journal of Business Studies Quarterly. Vol 3, N. 4, pp. 92-104.

Khan M.R, Ziauddin, Jam F.A. and Ramay M.I.

2010. The Infacts of Organizational Comitment ond Employee Job Performance.

Kreitner, Robert \& Angelo Kinichi. Organizational Behavior. New York: McGrow-Hill Companies, Inc. 2007

Luthans,

Fred. Perilaku Organisasi: edisi sepuluh

Alih bahasa oleh Vivin Andika Yuwono dkk. Yogyakarta: Andi. 2006.

Mowday, R., Steers, and Porter.

1979. The Measurement of Organizational Commitment. Journal of
Vacational Behavior 14, pp: 224-235

Nawawi, Hadari.

1993. Metode Penelitian Bidang Sosial. UGM Press. Yogyakarta.

Puji, I.

2009. Pengaruh Kepuasan kerja terhadap Semangat Kerja Karyawan Bagian Produksi Pada PT. Surya Sakti Utama Surabaya. Skripsi. Tidak Diterbitkan. Surabaya: Universitas Airlangga.

Riduwan.

2014. Dasar-Dasar Statistika. Bandung: Alfabeta.

Robbins, S. P., \& Judge T. A.

2008. Perilaku Organisasi: Edisi 12. Jakarta: Salemba Empat.

Sahertian, P., and Soetjipto, B.E.

2011. Improving Employee ${ }^{e e}$ Organizational Commitment, SelfEfficacy, and Organizational Citizenship Behavior Through the Implementation of Task-Oriented and RelationshipOriented Leadership Behavior, The Business Review, Cambridge, Vol 17, No 2, pp. 48-60.

Schatz, Kenneth \& Schatz, Linda.

1995. Keberhasilan Daya Pengaruh dalam Manajemen. Jakarta: Spektrum Mitra Utama Prentice Hall

Siswanto, Sastrohadiwiryo. 2003. Manajemen Tenaga Kerja Indonesi. Eedisi 2. PT. Bumi Aksara. Jakarta

Siswanto, Sastrohadiwiryo. 2003. Manajemen Tenaga Kerja Indonesi. Eedisi 2. PT. Bumi Aksara. Jakarta

Sudirman.

2015. Hasil UKG NTB 2015 mengecewakan. [online]. Halaman 1. Tersedia: http://www.radarlombok.co.id/ hasil-ukg-ntb-2015-mengcewakan.html. (16 Februari 2016) 
Sugiyono.

2009. Metode Penelitian Bisnis (Pendekatan Kuantitatif, Kualitatif, dan R\&D). Bandung: Alfabeta.

Werang, B.R.

2014. Pengaruh Kepemimpinan Transformasional Kepala Sekolah, Moral Kerja Guru, Dan Kepuasan Kerja Terhadap Kinerja Guru SDN di Kota Merauke. Cakrawala Pendidikan, Februari 2014, Th. XXXIII, No. 1, hlm. 128-137 